\title{
Serosurvey on rickettsiae of the spotted fever group and Rickettsia bellii among dogs in the state of Goiás, Brazil
}

\author{
Inquérito sorológico sobre riquétsias do grupo da febre maculosa e Rickettsia \\ bellii entre cães no estado de Goiás, Brasil
}

Lucianne Cardoso Neves'; Ana Laura Gonçalves Barreto'; Mariana Xavier de Souza'; Danieli Brolo Martins²; Amália Regina Mar Barbieri³; Maria Carolina de Azevedo Serpa3; Sebastián Muñoz-Leal3; Marcelo Bahia Labruna³; Felipe da Silva Krawczak* (1)

\begin{abstract}
'Laboratório de Doenças Parasitárias - LADOPAR, Setor de Medicina Veterinária Preventiva, Departamento de Medicina Veterinária, Escola de Veterinária e Zootecnia, Universidade Federal de Goiás - UFG, Goiânia, GO, Brasil

${ }^{2}$ Laboratório de Patologia Clínica, Hospital Veterinário, Escola de Veterinária e Zootecnia, Universidade Federal de Goiás - UFG, Goiânia, GO, Brasil

${ }^{3}$ Departamento de Medicina Veterinária Preventiva e Saúde Animal, Faculdade de Medicina Veterinária e Zootecnia, Universidade de São Paulo - USP, São Paulo, SP, Brasil
\end{abstract}

How to cite: Neves LC, Barreto ALG, Souza MX, Martins DB, Barbieri ARM, Serpa MCA, et al. Serosurvey on rickettsiae of the spotted fever group and Rickettsia bellii among dogs in the state of Goiás, Brazil. Braz J Vet Parasito/ 2020; 29(2): e021419. https:// doi.org/10.1590/S1984-29612020018

\begin{abstract}
The purpose of this study was to do a serological survey on three rickettsial species: Rickettsia rickettsii and Rickettsia parkeri, two species of the spotted fever group (SFG) that are considered to be great importance for public health; and Rickettsia bellii, a species of unknown pathogenicity that infects a variety of human-biting ticks. Serum samples from 273 dogs were tested using the indirect immunofluorescence assay (IFA). A total of 52 samples (19.04\%) were seropositive for at least one of the three Rickettsia spp. antigens. Thirty-eight (73.07\%), twelve (23.07\%) and one $(1.92 \%)$ of these dogs showed homologous reactions to $R$. bellii, $R$. rickettsii and $R$. parkeri, respectively. Our results showed that the seroprevalence of Rickettsia spp. was relatively low. However, the positive serological tests indicated that these dogs had become infected by these agents at some point in their lives. Lastly, our study adds to the previous knowledge on the epidemiology of rickettsiosis in the state of Goiás by doing the first record of detection of anti- $R$. rickettsii, $R$. parkeri and $R$. bellii antibodies by IFA among dogs, thus indicating that these agents may be circulating in the dog population analyzed.
\end{abstract}

Keywords: Rickettsia rickettsii, Rickettsia parkeri, IFA, Goiânia, Brazilian cerrado, tick-borne disease.

\begin{abstract}
Resumo
O objetivo deste estudo foi realizar um levantamento sorológico para três espécies de rickettsias: Rickettsia rickettsii e Rickettsia parkeri, duas espécies do grupo da febre maculosa (GFM) consideradas de grande importância para a saúde pública; e Rickettsia bellii, uma espécie de patogenicidade desconhecida que infecta uma variedade de carrapatos que parasitam seres humanos. Amostras de soro de 273 cães foram testadas, usando-se a técnica de reação de imunofluorescência indireta (RIFI). $O$ total de 52 amostras $(19,04 \%)$ foram soropositivas para pelo menos um dos três antígenos de Rickettsia spp. Trinta e oito $(73,07 \%)$, doze $(23,07 \%)$ e um $(1,92 \%)$ desses cães apresentaram reações homólogas à $R$. bellii, $R$. rickettsii e $R$. parkeri, respectivamente. Esses resultados demonstraram uma baixa soroprevalência para Rickettsia spp. No entanto, as amostras positivas indicam que esses cães foram infectados por esses agentes em algum momento de suas vidas. Por fim, este estudo contribui para o conhecimento sobre a epidemiologia das rickettsioses, no estado de Goiás, realizando a primeira deteç̧ão de anticorpos anti-Rickettsia rickettsii, R. parkeri e R. bellii pela RIFI em cães, indicando que esses agentes podem estar circulando na população canina analisada.
\end{abstract}

Palavras-chave: Rickettsia rickettsii, Rickettsia parkeri, RIFI, Goiânia, cerrado brasileiro, doença transmitida por carrapatos.

Received November 14, 2019. Accepted March 4, 2020

*Corresponding author: Felipe da Silva Krawczak. E-mail: felipekvet@gmail.com 
Rickettsia rickettsii is the etiological agent of Brazilian spotted fever (BSF), a reemerging zoonosis of extreme importance for public health because of the high fatality rate from this disease among humans ( $\geq 50 \%)$ (Brasil, 2017). In addition, Rickettsia parkeri strain Atlantic rainforest has been identified as the causative agent of an emerging spotted fever (SF) in different parts of Brazil (Spolidorio et al., 2010; Silva et al., 2011; Krawczak et al., 2016a). In particular, since 2010 in the state of Goiás - central-western region of Brazil, Cerrado biome - a total of 11 cases of SF without death records have been confirmed in the Disease Notification Information System (SINAN) in the following municipalities: Gameleira de Goiás (2), Goiânia (5), Guapó (1), Itumbiara (1), Jataí (1) and Mineiros (1) (Brasil, 2019), where knowledge about the disease is incipient.

Use of domestic dogs in seroepidemiological studies on rickettsiosis of the spotted fever group (SFG) constitutes a suitable approach for assessing possible infection caused by $R$. rickettsii and $R$. parkeri strain Atlantic rainforest in areas where the vectors of these agents, i.e. the ticks Amblyomma aureolatum and Amblyomma ovale, are present (Ogrzewalska et al., 2012; Szabó et al., 2013; Barbieri et al., 2014; Krawczak et al., 2016b). Domestic dogs may remain close to humans but may also enter natural areas where the vectors of SFG rickettsiosis are prevalent. If bitten by infected ticks, high titers of antibodies against Rickettsia spp. can be detected through the indirect immunofluorescence assay (IFA). Thus, dogs are excellent sentinels for assessing the epidemiological situation of SF in a single area (Horta et al., 2004; Ogrzewalska et al., 2012; Szabó et al., 2013; Barbieri et al., 2014; Krawczak et al., 2016c). Although cases of spotted fever have been confirmed in the state of Goiás (GO), current knowledge on the vectors, their associated hosts and the epidemiology of the disease in this state remains sparse (Brasil, 2019). In particular, no serological investigations among dogs from Goiânia, GO, Brazil, on SFG rickettsiae have yet been conducted.

Rickettsia bellii, a rickettsia that has been detected infecting more than 25 species of ticks, is considered non-pathogenic for animals and humans (Krawczak et al., 2018). However, it has been postulated that $R$. bellii could play a role in the ecology and epidemiology of several SFG rickettsiae through inhibiting their vertical transmission (transovarian transmission) to further generations of ticks (Parola et al., 2013; Sakai et al., 2014). In this context, the present study aimed to analyze the frequency of anti-R. rickettsii, $-R$. parkeri and $-R$. bellii antibodies in dogs from the cities in the South and Central mesoregions of Goiás that were attended at the Veterinary Hospital of the Federal University of Goiás (HV/EVZ/UFG), in Goiânia, GO.

Between November 2017 to February 2018, serum samples were collected from 273 dogs from the cities in the South and Central mesoregions of Goiás - Goiânia (243/273), Aparecida de Goiânia (11/273), Trindade (5/273), Santo Antônio de Goiás (3/273), Senador Canedo (3/273), Inhumas (1/273), Goianira (1/273), Itaguari (1/273), Itaguaru (1/273), Mossâmedes (1/273), Caturaí (1/273), Rio Quente (1/273) and Silvânia (1/273) (Table 1) - that were attended for routine clinical procedures, not necessarily related to vector-borne diseases. Serum samples from these animals were also assigned to other research projects that had been authorized by the Institutional Animal Care and Use Committee (IACUC) of the Federal University of Goiás (protocol 102/17). To detect anti-Rickettsia antibodies, serum samples were tested individually by means of the indirect immunofluorescence assay (IFA), using crude antigens derived from three Rickettsia isolates from Brazil (R. rickettsii strain Taiaçu, $R$. parkeri strain Atlantic rainforest and $R$. bellii strain Mogi), as previously described (Labruna et al., 2007). Briefly, the serum samples were diluted in twofold increments using phosphate-buffered saline (PBS), starting from the 1:64 dilution. Slides were incubated with fluorescein isothiocyanate-labelled rabbit anti-dog IgG (Sigma, St Louis, MO, USA).

For each sample, the endpoint IgG titer reacting with each of the three Rickettsia antigens was determined. Endpoints titers at least fourfold higher for one Rickettsia species than for the other Rickettsia species were considered to probably be homologous to the first species (Labruna et al., 2007). On each slide, a serum that had previously been shown to be non-reactive (negative control) and a known reactive serum (positive control), both from the studies of Piranda et al. (2008), were tested at the 1:64 dilution. These samples were obtained from the serum bank of the Laboratory of Parasitic Diseases, Department of Preventive Veterinary Medicine and Animal Health (VPS), School of Veterinary Medicine and Animal Science (FMVZ), University of São Paulo (USP), São Paulo, SP, Brazil.

Overall, $19.04 \%$ (52) of the dogs reacted (titer $\geq 64$ ) to at least one Rickettsia species. Totals of thirty-eight dogs (73.07\%), twelve (23.07\%) and one (1.92\%) were considered to have elicited homologous reactions to $R$. bellii, $R$. rickettsii and $R$. parkeri, respectively (Table 1 ).

The $19.04 \%$ overall rate of seroreactivity to Rickettsia spp. found in the present study was clearly lower than the overall canine seroprevalence rates (around 66\%) that have been reported for SFG-endemic areas in the southeastern and southern regions of Brazil (Sangioni et al., 2005; Barbieri et al., 2014). However, it was considerably higher than the seroprevalences of 5.63\% and 3\% that were observed by Rotondano et al. (2017) and Lopes et al. 
Table 1. Results regarding dogs seroreactivity to three Rickettsia species in the state of Goiás, central-western region of Brazil (November 2017 to February 2018).

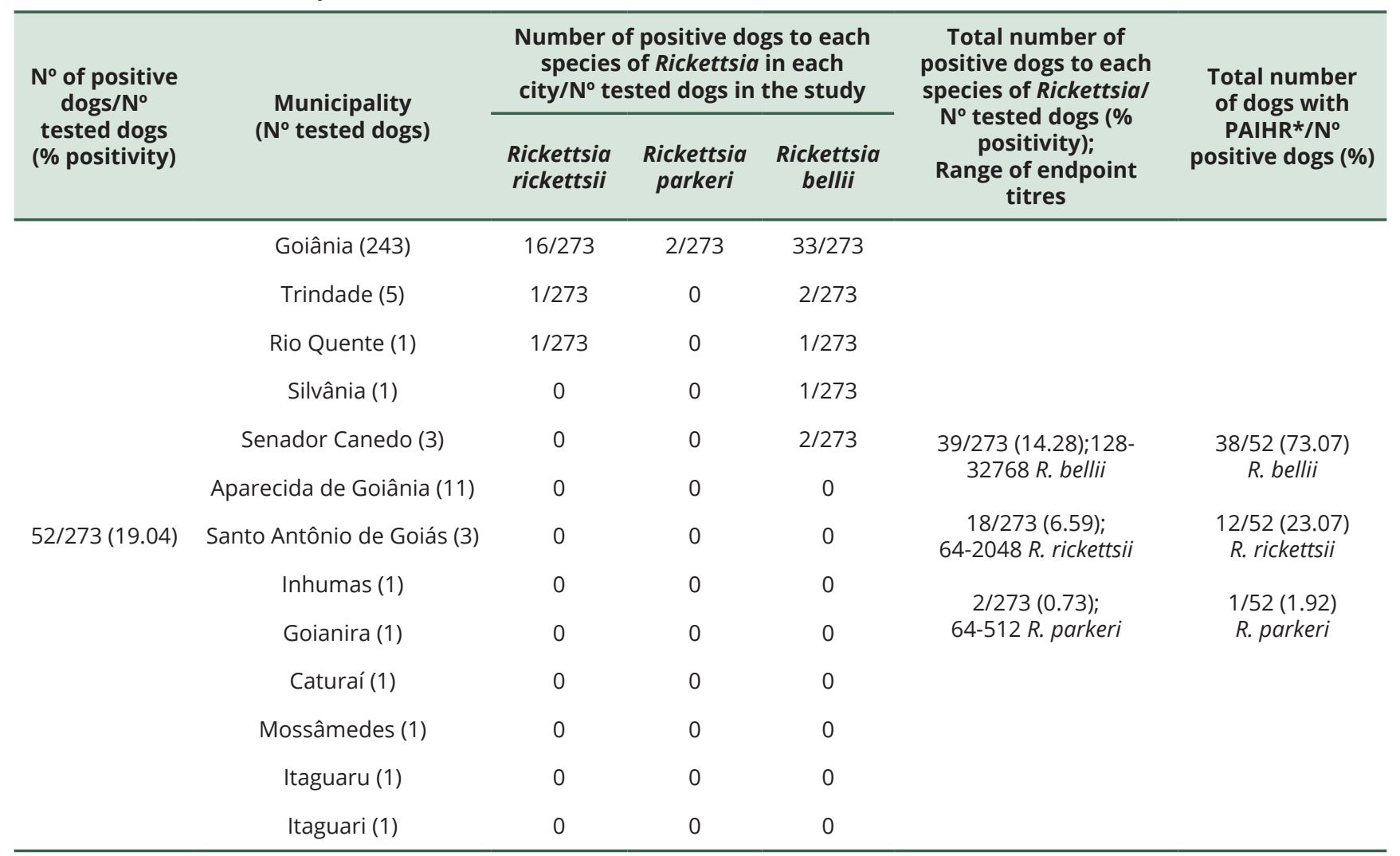

*PAIHR: probable antigen involved in homologous reaction.

(2019), respectively, in non-endemic areas in the northeastern region of Brazil. It was also higher than the $4.16 \%$ seropositivity for Rickettsia spp. that was found in a small population of 24 dogs that was analyzed in the city of Quirinópolis, GO, a region with suspected cases of SF (Martins et al., 2016a).

The finding of a low prevalence rate for circulation of SF bioagents does not downplay the importance of evaluating anti-Rickettsia spp. antibodies in sentinels such as dogs, which are common hosts for the ticks involved in SF epidemiology (Sangioni et al., 2005; Labruna et al., 2007; Brasil, 2019). Our results showed that 23.07\% (12/52) and $1.92 \%(1 / 52)$ of the samples were seroreactive to $R$. rickettsii and $R$. parkeri, respectively, which suggested that these dogs had become infected at some point in their lives. These Rickettsia species can be transmitted to animals by the ticks Rhipicephalus sanguineus sensu lato, A. aureolatum, A. ovale and Amblyomma sculptum (Ogrzewalska et al., 2012; Szabó et al., 2013). Despite these two rickettsiae are etiological agents for SFG rickettsiosis in humans in Brazil, only $R$. rickettsii has generated fatal cases to date (Szabó et al., 2013).

The higher frequency of seroreactivity for $R$. rickettsii among dogs (23.07\%) than for $R$. parkeri (1.92\%) highlights the possible exposure to A. sculptum, the vector for R. rickettsii in the Cerrado biome (Szabó et al., 2013). Under natural conditions, immature stages of $A$. sculptum have low host specificity, being able to parasitize humans and domestic dogs in this area (Szabó et al., 2013). However, in the present study the rate of tick infestation in dogs was not measured.

The occurrence of $A$. sculptum in the state of Goiás (Martins et al., 2016b), in addition to our finding regarding the frequency of anti- $R$. rickettsii antibodies, demonstrates that there is a possibility of $R$. rickettsii circulation and risk of infection in this region. On the other hand, the relevance of $R$. parkeri in the area studied here should not be underestimated because of its low seroprevalence, given that it is related to human SF cases and is transmitted by the tick $A$. ovale. This tick is found in several regions of the Brazilian Cerrado, including the state of Goiás (Spolidorio et al., 2010; Szabó et al., 2013; Krawczak et al., 2016a; Bitencourth et al., 2019). Rickettsia parkeri strain Atlantic rainforest was recently detected in $A$. ovale from Goiás, and further studies are needed in order to ascertain the distribution of this rickettsial species and its vector tick within this state (Bitencourth et al., 2019). The high 
seropositivity of dogs to $R$. bellii $(73.07 \%$; 38/52) found in the present study can be attributed to the fact that this rickettsial species frequently infects different tick species in Brazil, including those that parasitize dogs such as A. ovale, as reported by Labruna et al. (2011) and Costa et al. (2015), but its pathogenicity to humans and dogs is unknown (Krawczak et al., 2018).

Despite the higher seropositivity to $R$. rickettsii than to $R$. parkeri, the titers to $R$. rickettsii were lower $(\leq 2048)$ than those founded by Piranda et al. (2008) in experimentally infected dogs with $R$. rickettsii. Also, when comparing the seropositivity and titers to $R$. rickettsii (64-2048) and $R$. bellii (128-32768), there was a greater number of homologous dogs with higher titers for this second species, indicating more evidence of circulation and an exposure or reexposure recently of these animals to ticks infected with $R$. bellii (Piranda et al., 2008). These data may justify the absence of human SF fatal cases in the state of Goiás, since infections by $R$. parkeri are related to non-fatal cases and $R$. bellii has unknown pathogenicity for humans (Spolidorio et al., 2010; Silva et al., 2011; Krawczak et al., 2016a, 2018).

The findings from the present study underline the need for further investigations on the circulation of tick-borne rickettsiae in the region of Goiânia, either through using serological methods or by using molecular tools. Such studies would generate valuable data for determining occurrences of endemic areas for pathogenic Rickettsia species in the state of Goiás, which is important for public health given the severity of this disease. To our knowledge, this is the first study on detection of anti-R. rickettsii, $R$. parkeri and $R$. bellii antibodies by means of IFA among dogs in the state of Goiás. Our results indicate that these bioagents may be circulating in the dog population analyzed.

\section{References}

Barbieri ARM, Moraes J Fo, Nieri-Bastos FA, Souza JC Jr, Szabó MPJ, Labruna MB. Epidemiology of Rickettsia sp. strain Atlantic rainforest in a spotted fever-endemic area of southern Brazil. Ticks Tick Borne Dis 2014; 5(6): 848-853. http://dx.doi.org/10.1016/j. ttbdis.2014.07.010. PMid:25108786.

Bitencourth K, Amorim S, Oliveira S, Voloch C, Gazêta G. Genetic diversity, population structure and rickettsias in Amblyomma ovale in areas of epidemiological interest for spotted fever in Brazil. Med Vet Entomo/ 2019; 33(2): 256-268. http://dx.doi.org/10.1111/ mve.12363. PMid:30746741.

Brasil. Ministério da Saúde. Guia de vigilância em saúde: febre maculosa brasileira e outras riquetsioses [online]. 2. ed. Brasília: Ministério da Saúde; 2017 [cited 2019 Sept 15]. Available from: http://portalarquivos.saude.gov.br/images/pdf/2017/outubro/06/ Volume-Unico-2017.pdf

Brasil. Ministério da Saúde. Casos confirmados de febre maculosa: Brasil, Grandes Regiões e Unidades Federadas: 2000 a 2019 [online]. Brasília: Ministério da Saúde; 2019 [cited 2019 Aug 20]. Available from: https://portalarquivos2.saude.gov.br/images/ pdf/2019/junho/14/Casos-de-Febre-Maculosa.pdf

Costa AP, Costa FB, Labruna MB, Silveira I, Moraes J Fo, Soares JF, et al. A serological and molecular survey of Babesia vogeli, Ehrlichia canis and Rickettsia spp. among dogs in the state of Maranhão, northeastern Brazil. Rev Bras Parasitol Vet 2015; 24(1): 28-35. http://dx.doi.org/10.1590/S1984-29612015008. PMid:25909250.

Horta MC, Vianna MCB, Mafra CL, Schumaker TTS, Walker DH, Galvão MAM, et al. Prevalence of antibodies to spotted fever group rickettsiae in humans and domestic animals in a brazilian spotted fever-endemic area in the state of São Paulo, Brazil: serologic evidence for infection by Rickettsia Rickettsii and another spotted fever group rickettsia. Am J Trop Med Hyg 2004; 71(1): 93-97. http://dx.doi.org/10.4269/ajtmh.2004.71.93. PMid:15238696.

Krawczak FS, Agostinho WC, Polo G, Moraes J Fo, Labruna MB. Comparative evaluation of Amblyomma ovale ticks infected and noninfected by Rickettsia sp. strain Atlantic rainforest, the agent of an emerging rickettsiosis in Brazil. Ticks Tick Borne Dis 2016b; 7(3): 502-507. http://dx.doi.org/10.1016/j.ttbdis.2016.02.007. PMid:26895674.

Krawczak FS, Binder LC, Oliveira CS, Costa FB, Moraes J Fo, Martins TF, et al. Ecology of a tick-borne spotted fever in southern Brazil. Exp Appl Acarol 2016c; 70(2): 219-229. http://dx.doi.org/10.1007/s10493-016-0070-1. PMid:27392739.

Krawczak FS, Labruna MB, Hecht JA, Paddock CD, Karpathy SE. Genotypic characterization of Rickettsia bellii Reveals Distinct Lineages in the United States and South America. BioMed Res Int 2018; 2018: 8505483. http://dx.doi.org/10.1155/2018/8505483. PMid:29850579.

Krawczak FS, Oliveira SV, Guztzazky AC, Labruna MB, Muñoz-Leal S, Souza JC, et al. Case report: Rickettsia sp. strain atlantic rainforest infection in a patient from a spotted fever-endemic area in southern Brazil. Am J Trop Med Hyg 2016a; 95(3): 551-553. http://dx.doi.org/10.4269/ajtmh.16-0192. PMid:27325804.

Labruna MB, Horta MC, Aguiar DM, Cavalcante GT, Pinter A, Gennari SM, et al. Prevalence of Rickettsia infection in dogs from the urban and rural areas of Monte Negro municipality, Western Amazon, Brazil. Vector Borne Zoonotic Dis 2007; 7(2): 249-255. http://dx.doi.org/10.1089/vbz.2006.0621. PMid:17627445. 
Labruna MB, Salim Mattar V, Nava S, Bermudez S, Venzal JM, Dolz G, et al. Rickettsioses in Latin America, Caribbean, Spain and Portugal. Rev Mvz Cordoba 2011; 16(2): 2435-2457. http://dx.doi.org/10.21897/rmvz.282.

Lopes MG, Krawczak FS, Lima JTR, Fournier GFSR, Acosta ICL, Ramirez DG, et al. Occurrence of Ehrlichia canis and Hepatozoon canis and probable exposure to Rickettsia amblyommatis in dogs and cats in Natal, RN. Rev Bras Parasito/ Vet 2019; 28(1): $151-156$. http://dx.doi.org/10.1590/s1984-296120180065. PMid:30462820.

Martins MEP, Brito WMED, Labruna MB, Moraes J Fo, Sousa-Martins KC, Vieira RP. Epidemiological survey of supposed spotted fever outbreak. Cienc Anim Bras 2016a; 17(3): 459-471. http://dx.doi.org/10.1590/1089-6891v17i334947.

Martins TF, Barbieri ARM, Costa FB, Terassini FA, Camargo LMA, Peterka CRL, et al. Geographical distribution of Amblyomma cajennense (sensu lato) ticks (Parasitiformes: Ixodidae) in Brazil, with description of the nymph of $A$. cajennense (sensu stricto). Parasit Vectors 2016b; 9(1): 186. http://dx.doi.org/10.1186/s13071-016-1460-2. PMid:27036324.

Ogrzewalska M, Saraiva DG, Moraes J Fo, Martins TF, Costa FB, Pinter A, et al. Epidemiology of Brazilian spotted fever in the Atlantic Forest, state of São Paulo, Brazil. Parasitology 2012; 139(10): 1283-1300. http://dx.doi.org/10.1017/S0031182012000546. PMid:22716923.

Parola P, Paddock CD, Socolovschi C, Labruna MB, Mediannikov O, Kernif T, et al. Update on tick-borne rickettsioses around the world: A geographic approach. Clin Microbiol Rev 2013; 26(4): 657-702. http://dx.doi.org/10.1128/CMR.00032-13. PMid:24092850.

Piranda EM, Faccini JLH, Pinter A, Saito TB, Pacheco RC, Hagiwara MK, et al. Experimental infection of dogs with a Brazilian strain of Rickettsia rickettsii: clinical and laboratory findings. Mem Inst Oswaldo Cruz 2008; 103(7): 696-701. http://dx.doi.org/10.1590/ S0074-02762008000700012. PMid:19057821.

Rotondano TEF, Krawczak FS, Barbosa WO, Moraes J Fo, Bastos FN, Labruna MB, et al. Ehrlichia canis and Rickettsia spp. in dogs from urban areas in Paraiba state, northeastern Brazil. Rev Bras Parasitol Vet 2017; 26(2): 211-215. http://dx.doi.org/10.1590/ s1984-29612017030. PMid:28658415.

Sakai RK, Costa FB, Ueno TEH, Ramirez DG, Soares JF, Fonseca AH, et al. Experimental infection with Rickettsia rickettsii in an Amblyomma dubitatum tick colony, naturally infected by Rickettsia bellii. Ticks Tick Borne Dis 2014; 5(6): 917-923. http://dx.doi. org/10.1016/j.ttbdis.2014.07.003. PMid:25108783.

Sangioni LA, Horta MC, Vianna MCB, Gennari SM, Soares RM, Galvão MAM, et al. Rickettsial infection in animals and brazilian spotted fever endemicity. Emerg Infect Dis 2005; 11(2): 265-270. http://dx.doi.org/10.3201/eid1102.040656. PMid:15752445.

Silva N, Eremeeva ME, Rozental T, Ribeiro GS, Paddock CD, Ramos EAG, et al. Eschar-associated Spotted Fever Rickettsiosis, Bahia, Brazil. Emerg Infect Dis 2011; 17(2): 275-278. http://dx.doi.org/10.3201/eid1702.100859. PMid:21291605.

Spolidorio MG, Labruna MB, Mantovani E, Brandão PE, Richtzenhain LJ, Yoshinari NH. Novel Spotted Fever Group Rickettsiosis, Brazil. Emerg Infect Dis 2010; 16(3): 521-523. http://dx.doi.org/10.3201/eid1603.091338. PMid:20202436.

Szabó MPJ, Pinter A, Labruna MB. Ecology, biology and distribution of spotted-fever tick vectors in Brazil. Front Cell Infect Microbiol 2013; 3: 27. http://dx.doi.org/10.3389/fcimb.2013.00027. PMid:23875178. 